\title{
The DOM characteristic in As-affected aquifer of Chaobai River in the North China Plain
}

\author{
Y.F. Jia ${ }^{1,2} \&$ Y.H. Jiang ${ }^{1,2}$ \\ ${ }^{1}$ State Key Laboratory of Environmental Criteria and Risk Assessment, Chinese Research Academy of Environmental \\ Sciences, Beijing, P.R. China \\ ${ }^{2}$ State Environmental Protection Key Laboratory of Simulation and Control of Groundwater Pollution, \\ Chinese Research Academy of Environmental Sciences, Beijing, P.R. China
}

\begin{abstract}
High As groundwater was found in Chaobai River aquifers of North China Plain (NCP) which poses risk to drinking water resource. Arsenic shows patchy distribution in both horizontal and vertical profiles with concentration of $<0.1-304 \mu \mathrm{g} \mathrm{L}^{-1}$. The enrichment of As is related to reductive dissolution, supported by contradictory distribution of As and $\mathrm{NO}_{3}^{-}$, negative correlation between $\mathrm{As}$ and $\mathrm{SO}_{4} / \mathrm{Cl}$, and positive and then negative trend between As and Fe. DOM decomposition was evidenced by positive link between As and P. Four florescence components were identified in groundwater DOM including humic acid-like, fulvic acid-like and two kinds of protein-like substances. Arsenic concentration shows negative correlation with humic substances (HS) except for the sample with the highest As. It seems that HS may enhance As mobilization possibly via electron shuttle or complexation effect only when it is in high content. The river water which is characterized with high humic-like substances would infiltrate to supply more HS to groundwater and further promotes As mobilization.
\end{abstract}

\section{INTRODUCTION}

High arsenic (As) groundwater is a worldwide environment issue, of which mostly occurred in reducing condition with dissolved organic matter (DOM) prevailing. Reactive DOM is believed to stimulate dissimilatory reduction of iron oxides/hydroxides which is accompanied by $\mathrm{As}(\mathrm{V})$ reduction and release of $\mathrm{As}(\mathrm{III})$. Recently, humic substance (HS) which is a large proportion of DOM is regarded as electron shuttle to enhance $\mathrm{Fe}$ (III) reduction and As release in Bangladesh aquifers (Mladenov et al., 2015). Based on these findings, DOM characterization in high Asaffected aquifers seems to be the first step to identify these processes. In this study, Chaobai River Watershed which was found to have high As groundwater was selected to see As mobilization patterns and related DOM characteristic in aquifers.

\section{MATERIALS AND METHODS}

\subsection{The study area}

The Chaobai River originating in Northern Yanshan Mountain flows through Beijing, Hebei and Tianjin and terminates to the Bohai Sea. It lies in the northern part of North China Plain (NCP) with prevailing semiarid and semi-humid climates. The annual precipitation and water surface evaporation are around $560 \mathrm{~mm}$ and $1100 \mathrm{~mm}$, respectively. Sand and partly gravel prevails in this Holocene porous aquifer. Precipitation and river water infiltration are the main recharge sources for groundwater. The need for drinking water causes a large amount of abstraction further the decline of groundwater table which shows an average rate of $2.8 \mathrm{~m} \mathrm{yr}^{-1}$ in part of area. The study area is located in the upper reach of the river known as the Shunyi district of Beijing. One major drinking water plant is located in this area, indicating an urgent need to deal with the groundwater quality problem and its further evolution.

\subsection{Sampling and analysis methods}

Sixty groundwater samples were collected from wells at depths of $30,50,80$ and $150 \mathrm{~m}$ as well as 6 surface river water samples. Major anions were determined using Ion Chromatography (DX-120, Dionex), major cations, $\mathrm{Fe}, \mathrm{Mn}$ and $\mathrm{As}$ by Inductively Coupled Plasma Atomic Emission Spectroscopy (iCAP 6300, Thermo). Fluorescence spectroscopy was determined using a Hitachi F-7000 fluorescence spectrophotometer. Three-dimensional fluorescence excitation emission matrices (EEMs) were generated by scanning samples over an excitation range of 200$450 \mathrm{~nm}$ at $5 \mathrm{~nm}$ increments and an emission range of $280-550 \mathrm{~nm}$ at $5 \mathrm{~nm}$ increments. Hierarchical cluster analysis (HCA) was performed on all samples with Ward's method, which uses the squared Euclidean distance as a similarity measure. 


\section{RESULTS AND DISCUSSION}

\subsection{As mobilization patterns}

Arsenic shows patchy distribution with concentration of $<0.1-304 \mu \mathrm{g} \mathrm{L}^{-1}$. Eleven of total 60 samples have As $>10 \mu \mathrm{g} \mathrm{L}^{-1}$, of which 7 above $50 \mu \mathrm{g} \mathrm{L}^{-1}$. Arsenic concentration in river water is below the detection limit. High arsenic groundwater was observed in all depth range, indicating a heterogeneous aquifer environment or the different influence of river water infiltration. Nitrate shows high and varied concentration in groundwater $\left(<0.1-90.4 \mathrm{mg} \mathrm{L}^{-1}\right)$ as well as the river water $\left(1.43-93.0 \mathrm{mg} \mathrm{L}^{-1}\right)$. Contradictory distribution was found between $\mathrm{As}$ and $\mathrm{NO}_{3}^{-}$with high As groundwater $\left(>10 \mu \mathrm{g} \mathrm{L}^{-1}\right)$ have $\mathrm{NO}_{3}^{-}$all below $6 \mathrm{mg} \mathrm{L}^{-1}$. Although As specie is not determined, it could be concluded that As(III) is more likely to be dominant. Arsenic shows a positive correlation with aqueous $\mathrm{Fe}$ when As below $100 \mu \mathrm{gL}^{-1}$, however reverse trend was found between them when As is higher, which is similar with the case in Hetao Basin (Jia et al., 2014). An obvious decline trend of $\mathrm{SO}_{4} / \mathrm{Cl}$ ratio was observed when As concentration increases. Total $\mathrm{P}$ showed liner and positive correlation with As when As $>10 \mu \mathrm{g} \mathrm{L}^{-1}$. These distribution patterns of As and other redox-sensitive components clearly indicate the scenario of reductive dissolution of $\mathrm{Fe}$ and related As release (Jia et al., 2017). DOM decomposition plays a critical role in this process and regulating As release.

\subsection{DOM character in high and low As groundwater}

Fluorescence spectroscopy helps to reveal different kind of DOM components. EEMs were delineated into five excitation-emission regions including Region I, II being aromatic protein-like, Region III fulvic acidlike, Region IV soluble microbial by-product-like, and Region V humic acid-like (Chen et al., 2003). The volume of each region represents the cumulative fluorescence response of DOM with similar properties. Generally, As concentration shows positive correlation with total volume of region I, II, and IV, while negative correlation with total volume of region III and $\mathrm{V}$ known as HS except for the sample with the highest As. It is dominated by humic acid-like substances, which account for $83.3 \%$ of total 5 regions volume. The volume of region $\mathrm{V}$ in this sample is the highest value of all samples as well. Therefore, it seems to be ineffective to As mobilization when humic acid-like substances is not in high content. Similar case shows at least $5 \mathrm{mg} \mathrm{L}^{-1} \mathrm{HS}$ is needed to stimulate microbial ferrihydrite reduction (Jiang et al., 2008).

Four florescence components were identified by EEM spectra coupled with PARAFAC analysis. It shows that components 1 and 2 are originated from humic acid-like, and fulvic acid-like substances, respectively, while components 3 and 4 from proteinlike substances. Arsenic concentration shows negative correlation with HS (components 1 and 2) except for the highest As sample. However, no significant pattern were found between As and protein-like substances (components 3 and 4).

\section{CONCLUSIONS}

This is just a preliminary analysis of DOM in high As aquifers in Chaobai River. The enrichment of As is related to reducing environment attributed by DOM decomposition. However, the specific component of DOM working for this process was not identified. HS may impact As mobilization explained as electron shuttle or complexation effect. However, in this area it may need to be in high content before it works. The concerning thing is that river water which is characterized with high humic-like substances would infiltrate to supply more HS to groundwater, its effect on As mobilization merit further investigation.

\section{ACKNOWLEDGEMENTS}

This work was supported by the National Water Pollution Control and Treatment Science and Technology Major Project (No. 2018ZX07109-003, 004).

\section{REFERENCES}

Chen, W., Westerhoff, P., Leenheer, J. A. \& Booksh, K. 2003. Fluorescence excitation-emission matrix regional integration to quantify spectra for dissolved organic matter. Environ. Sci. Technol. 37(24): 5701-5710.

Jia, Y.F., Guo, H.M., Jiang, Y.X., Wu. Y. \& Zhou, Y.Z. 2014. Hydrogeochemical zonation and its implication for arsenic mobilization in deep groundwaters near alluvial fans in the Hetao Basin, Inner Mongolia. J. Hydrol. 518: 410-420.

Jia, Y.F., Guo, H.M., Xi, B.D., Jiang, Y.H., Zhang, Z., Yuan, R.X., Yi, W.X. \& Xue, X.L. 2017. Sources of groundwater salinity and potential impact on arsenic mobility in the western Hetao Basin, Inner Mongolia. Sci. Total Environ. 601-602: 691-702

Jiang, J. \& Kappler, A. 2008. Kinetics of microbial and chemical reduction of humic substances: implications for electron shuttling. Environ. Sci. Technol. 42(10): 35633569.

Mladenov, N., Zheng, Y., Simone, B., Bilinski, T.M., McKnight, D.M., Nemergut, D., Radloff, K.A., Rahman M.M. \& Ahmed, K.M. 2015. Dissolved organic matter quality in a shallow aquifer of Bangladesh: implications for arsenic mobility. Environ. Sci. Technol. 49(18): 10815-10824. 